(c) American Dairy Science Association, 2007.

\title{
Measurement of Milk Intake in Suckling Llamas (Lama glama) Using Deuterium Oxide Dilution
}

\author{
A. Riek, ${ }^{1}$ M. Gerken, and E. Moors \\ Institute of Animal Breeding and Genetics, University of Goettingen, Albrecht-Thaer-Weg 3, D-37075 Goettingen, Germany
}

\begin{abstract}
The objective of the study was to estimate daily milk intake in llama crias and relate nutrient intakes at peak lactation to growth data. Milk intake in 11 suckling llamas was estimated from water kinetics using deuterium oxide $\left(\mathrm{D}_{2} \mathrm{O}\right)$ at $\mathrm{d} 17,66$, and 128 postpartum. Daily milk intakes averaged $2.6,2.3$, and $2.0 \mathrm{~kg}$ at 17 , 66 , and $128 \mathrm{~d}$ postpartum, respectively. Milk intake decreased with age when expressed as daily amount, percentage of body weight (BW), or per kilogram of metabolic size, but the influence of age was eliminated when expressed per gram of daily gain. Because llamas only have one young per parturition, milk intake was equivalent to the daily milk output of the dam, which ranged from 27.6 to $96.9 \mathrm{~g} / \mathrm{kg}$ of maternal $\mathrm{BW}^{0.75}$. Compared with different ruminant species, milk production in llamas appears to lie between wild and domestic ruminants used for meat production. Nutrients (dry matter, fat, protein, and lactose) and energy intakes from the milk calculated by combining milk intake and milk composition data decreased with age when expressed as daily amount or per $100 \mathrm{~g}$ of BW, but when expressed per gram of daily gain, no clear trend was observed. Maintenance requirement for suckling llamas at peak lactation ( $17 \mathrm{~d}$ postpartum) was $312 \mathrm{~kJ}$ of $\mathrm{ME} / \mathrm{kg}$ of BW $\mathrm{BW}^{0.83}$. Combined with milk composition data, the present milk intake estimations at different stages of the lactation can be used to establish recommendations for nutrient and energy requirements of suckling llamas.
\end{abstract}

Key words: llama, milk intake, deuterium dilution, lactation

\section{INTRODUCTION}

Knowledge of the composition and production of llama milk is essential for a better understanding of the nutrient requirements of both the dam and the nursing llama (cria).

Received April 28, 2006.

Accepted August 24, 2006.

${ }^{1}$ Corresponding author: ariek@gwdg.de
There exist some studies on llama milk composition (Fernandez and Oliver, 1988; Morin et al., 1995), but only one analyzing the milk constituents over a 27 -wk lactation period (Riek and Gerken, 2006). Milk yield estimates ranging from 0.4 to $1.2 \mathrm{~L} / \mathrm{d}$ have been reported for the alpaca (Leyva and Markas, 1991). However, to the authors' knowledge there are no published data on either llama milk yield or milk intake. Hand milking is hardly applicable to llamas due to the short teats (about $2 \mathrm{~cm}$; Fowler, 1989). In addition, the storage capacity of the udder is very limited, and milking would be required every 2 to $3 \mathrm{~h}$ to approximate the natural suckling interval of nursing llamas (Pouillon, 2001).

Suckling behavior has been used to estimate the amount of milk transferred (Gauthier and Barrette, 1985), but the meta-analysis of Cameron (1998) revealed only a weak relationship between milk transfer and suckling behavior. The double-weighing procedure (weighing the animal before and after milk intake) often underestimates milk transfer and is subject to increasing measurement errors as the weight of the young increases (Garcia et al., 1999).

The isotope-labeling technique using 1 hydrogen isotope (Macfarlane et al., 1969) has been widely used to measure milk intake in suckling humans (Caire et al., 2002) and various animal species, including sheep (Oftedal, 1981), swine (Glencross et al., 1997), and cattle (Auchtung et al., 2002), but not llamas. Deuterium oxide $\left(\mathrm{D}_{2} \mathrm{O}\right)$ has provided valid estimates of milk intake if corrections for changes in body pool size of the growing young are made (Oftedal, 1984). The procedure quantifies milk intake by the nursing young with a minimum of disruption of the normal suckling behavior.

The objectives of the study were to estimate daily milk intake in llama crias in 3 measurement periods using $\mathrm{D}_{2} \mathrm{O}$ dilution and to relate nutrient intakes at peak lactation to growth data. In addition, milk intake was evaluated as indirect measure of the dam's milk output.

\section{MATERIALS AND METHODS}

\section{Animals and Management}

Eleven female llamas and their nursing young (crias) were involved in 2 trials. Animals originated from the 
RIEK ET AL.

Table 1. Characteristics of the lactating llamas and their crias under study

\begin{tabular}{lccllll}
\hline Trial & Animal & $\begin{array}{l}\text { Age } \\
(\mathrm{yr})\end{array}$ & $\begin{array}{l}\text { Weight } \\
(\mathrm{kg})\end{array}$ & $\begin{array}{l}\text { Parturition } \\
(\mathrm{mo})\end{array}$ & $\begin{array}{l}\text { Sex } \\
\text { of cria }\end{array}$ & $\begin{array}{l}\text { Lactation } \\
\text { number }\end{array}$ \\
\hline I: Jul 2004 to Feb 2005 & 1 & 12 & 149.0 & August & Female & 7 \\
& 2 & 12 & 142.0 & August & Female & 6 \\
& 3 & 11 & 171.5 & July & Male & 5 \\
& 4 & 10 & 110.0 & August & Male & 6 \\
& 5 & 6 & 167.0 & July & Male & 1 \\
II: May to Nov 2005 & 6 & 4 & 114.0 & July & Female & 1 \\
& 7 & 4 & 110.5 & August & Female & 1 \\
& 8 & 5 & 180.5 & May & Female & 2 \\
& 9 & 5 & 146.0 & May & Female & 2 \\
& 10 & 9 & 160.0 & May & Female & 4 \\
\hline
\end{tabular}

herd of the Experimental Station Relliehausen of Goettingen University and a private German breeder. Animals were transferred 3 mo before parturition for acclimation and were kept at the Institute of Animal Breeding and Genetics (University of Goettingen, Germany) for a lactation period of $27 \mathrm{wk}$ under controlled, stable conditions. Each room measured 5.8 by $3.2 \mathrm{~m}$, and animals had permanent access to an outdoor pen. In the stable, the light schedule was kept constant (14 h light to $10 \mathrm{~h}$ dark). Details of the experimental arrangements are given in Table 1. Llama dams were fed twice daily $0.5 \mathrm{~kg}$ of a commercial mixed grain and molasses feed containing $16.0 \% \mathrm{CP}, 12.0 \%$ crude fiber, $3.0 \%$ crude fat, $1.2 \%$ calcium, $0.5 \%$ phosphorus, $0.3 \%$ sodium, $8.5 \%$ ash, and $10.2 \mathrm{MJ}$ of ME/kg (HG $58 \mathrm{~S}$, Raiffeisen-AGRAVIS AG, Rosdorf, Germany). Hay from ryegrass-dominated grassland (DM: $860 \mathrm{~g} / \mathrm{kg}$ of fresh matter, crude ash: 94 $\mathrm{g} / \mathrm{kg}$ of DM, CP: $131 \mathrm{~g} / \mathrm{kg}$ of DM, ether extract: $26 \mathrm{~g} / \mathrm{kg}$ of DM, crude fiber: $283 \mathrm{~g} / \mathrm{kg}$ of DM, and nitrogen free extractives: $466 \mathrm{~g} / \mathrm{kg}$ of DM). Water and mineral supplement (HG MIN 13, Raiffeisen-AGRAVIS AG) were available ad libitum.

Crias had access to hay in both trials because hay was considered a negligible source of extraneous water for the measurement periods. Water intake by the crias was restricted to dams' milk until wk 10 postpartum (PP), because in a pretrial, crias did not start to consume drinking water until wk $11 \mathrm{PP}$. After that, crias had access to water ad libitum, except for the measurement periods when water intake was restricted to milk water.

\section{Milk Intake Studies}

Milk intake was estimated from water kinetics in 11 crias during 3 sampling periods at 3,10 , and 18 wk PP, lasting 7, 4, and $2 \mathrm{~d}$, respectively. Measurements were calculated for the midpoint of each study period; that is, 17, 66, and $128 \mathrm{~d}$ PP. Crias were separated from their dams $2 \mathrm{~h}$ before the treatment. Before the isotope administration a background blood sample was taken in blood tubes containing citrate. Deuterium oxide of 99.90\% purity (Euriso-top GmbH, Saarbruecken, Germany) was then injected intramuscularly at 2 body sites in volumes between 5 and $10 \mathrm{~mL}$. The individual amount administered was determined by the weight of the cria, which was measured with a scale (model CW3P1-150IG-I, Sartorius AG, Goettingen, Germany) to the nearest $0.005 \mathrm{~kg}$, directly before the isotope application. The amounts administered (per kg of BW) were $0.310 \pm 0.015 \mathrm{~g}, 0.206 \pm 0.015 \mathrm{~g}$, and $0.148 \pm 0.022 \mathrm{~g}$ (mean $\pm \mathrm{SD}$ ), at wk 3,10 , and $18 \mathrm{PP}$, respectively. The actual dose given was gravimetrically measured by weighing the syringe before and after the administration to the nearest $0.001 \mathrm{~g}$. After administration, crias remained separated from their dams for another $2 \mathrm{~h}$. Blood samples $(6 \mathrm{~mL})$ were then taken from the jugular vein every 0.5 to $2 \mathrm{~d}$ for each measurement period. Body weight was also recorded at the end of each measuring period to determine daily growth.

Blood samples were centrifuged, and approximately $3 \mathrm{~mL}$ of plasma was pipetted into glass vials and then frozen at $-20^{\circ} \mathrm{C}$ until the determination of $\mathrm{D}_{2} \mathrm{O}$ concentration. Water from 16 plasma samples was isolated by vacuum sublimation (Oftedal and Iverson, 1989). For comparison of the accuracy of the methods, both plasma and the extracted water from the same samples were analyzed for $\mathrm{D}_{2} \mathrm{O}$ concentration. The difference between the corresponding analyses was less than $1.5 \%$, and only plasma samples were further analyzed for $\mathrm{D}_{2} \mathrm{O}$ concentration. Analyses were conducted at the Competence Center of Stable Isotopes (KOSI Goettingen University). Deuterium concentrations of the plasma were measured in the hydrogen gas derived by zinc reduction (Wong and Schoeller, 1990) conducted in a Finnigan HDevice (Thermo Electron Corp., Bremen, Germany). Hydrogen isotope ratios were measured in a Finnigan Delta plus spectrometer (Thermo Electron Corp.) and expressed in delta/mL relative to Vienna standard mean ocean water (VSMOW), which is the interna- 
tional reference standard for $\mathrm{D}_{2} \mathrm{O}$, where delta $(\delta)$ is calculated as:

$$
\delta=
$$

[(Isotopic ratio of sample/Isotopic ratio of VSMOW)

$$
-1] \times 1,000 .
$$

Individual samples were measured in triplicate, and the averages calculated. Measured isotope concentrations in plasma samples were corrected for changes in pool size for each cria according to the formula:

$$
\mathrm{C}_{\mathrm{t}} * \mathrm{C}_{\mathrm{t}} \times\left(\mathrm{BW}_{\mathrm{t}} / \mathrm{BW}_{0}\right)
$$

where $\mathrm{C}_{\mathrm{t}}{ }^{*}$ is the resulting corrected isotope concentration at time $\mathrm{t}$ after administration, $\mathrm{C}_{\mathrm{t}}$ is the measured isotope concentration at time $\mathrm{t}, \mathrm{BW}_{\mathrm{t}}$ is the corresponding $\mathrm{BW}$ of that time, and $\mathrm{BW}_{0}$ is the $\mathrm{BW}$ at the beginning of the trial. It was assumed that body water comprises a constant proportion of BW during the respective measurement period.

Isotope equilibration concentration and fractional water turnover of the isotope was computed for each cria by extrapolating the regression of the natural logarithm of $\mathrm{C}_{\mathrm{t}}$ * on time by the regression equation

$$
\ln \mathrm{C}_{\mathrm{t}}{ }^{*}=\ln \mathrm{C}_{0}-\mathrm{k} \times \mathrm{t}
$$

or

$$
\mathrm{C}_{\mathrm{t}} *=\mathrm{C}_{0} \times \mathrm{e}^{-\mathrm{k} \times \mathrm{t}}
$$

where $\mathrm{C}_{0}$ is the equilibration concentration (intercept), $\mathrm{k}$ is the fractional water turnover (slope) and $\mathrm{t}$ is the time elapsed since tracer administration (Holleman et al., 1982). Isotope equilibration and predose baseline concentration was then used to calculate the initial $\mathrm{D}_{2} \mathrm{O}$ dilution space which was considered to reflect the total body water (TBW) in kilograms by using the formula from Schoeller et al. (1986):

$$
\begin{aligned}
\mathrm{TBW}=[\mathrm{D} & \left.\times \mathrm{APE}_{\text {dose }} \times 18.02 \mathrm{~g} / \mathrm{mole}\right] /\left[\mathrm{MW}_{\text {dose }}\right. \\
& \left.\times 100 \times\left(\mathrm{C}_{0}-\mathrm{C}_{\mathrm{b}}\right) \times \mathrm{R}_{\text {std }}\right]
\end{aligned}
$$

where $\mathrm{D}=$ dose given (grams), $\mathrm{APE}_{\text {dose }}=$ atomic enrichment of the dose in percent $(=99.90 \%), \mathrm{MW}_{\text {dose }}=$ molecular weight of the dose $\left(\mathrm{D}_{2} \mathrm{O}=20.02\right), \mathrm{C}_{0}=$ isotope equilibration concentration expressed as delta vs. VSMOW, $\mathrm{C}_{\mathrm{b}}=$ predose baseline concentration, and $\mathrm{R}_{\mathrm{std}}=$ ratio of deuterium to hydrogen in the VSMOW; i.e., $1.5574 \times 10^{-4}$.

Final pool size was calculated by multiplying the ratio of initial pool size to initial BW by the final BW. Daily water intake was calculated according to (Oftedal et al., 1983):

$$
\mathrm{WI}=\mathrm{L}+\mathrm{G}=\mathrm{TBW}_{\text {avg }} \times \mathrm{k}+\Delta \mathrm{TBW}
$$

where WI = daily water intake, $\mathrm{L}=$ amount of daily water lost, $\mathrm{G}=$ amount of daily water stored, $\mathrm{TBW}_{\mathrm{avg}}=$ body water pool size at the midpoint of the study, $\mathrm{k}=$ daily water turnover rate, and $\triangle \mathrm{TBW}=$ daily change in pool size. To convert total daily water intake to daily milk intake for each cria, knowledge of both the free water content of milk consumed and metabolic water production from catabolism of fat and protein is required; and it is assumed that the ingested lactose is completely metabolized. Accordingly, estimates of daily milk intakes were calculated after the method of Oftedal and Iverson (1989):

$$
\begin{gathered}
\mathrm{MI}=\left[\mathrm{WI}+1.07 \times \mathrm{F}_{\mathrm{d}}+0.42 \times \mathrm{P}_{\mathrm{d}}\right] /[(100-\% \mathrm{DM}) \\
+(\% \mathrm{P} \times 0.42)+(\% \mathrm{~F} \times 1.07)+(\% \mathrm{~L} \times 0.58)] \\
\times 100
\end{gathered}
$$

where MI is daily milk intake $(\mathrm{kg}), \mathrm{F}_{\mathrm{d}}$ and $\mathrm{P}_{\mathrm{d}}$ are daily deposition $(\mathrm{kg})$ of fat and protein, $\% \mathrm{DM}, \% \mathrm{P}, \% \mathrm{~F}$, and $\% \mathrm{~L}$ are the DM, protein, fat, and lactose contents of milk, respectively. Fat and protein produce 1.07 and $0.42 \mathrm{~g}$ of water/g of material oxidized (Van Es, 1969). The water yield of lactose was computed as $0.58 \mathrm{~g} / \mathrm{g}$ of material oxidized, on the basis of its chemical composition $\left(\mathrm{C}_{12} \mathrm{H}_{22} \mathrm{O}_{11}\right)$. In the absence of direct data on fat and protein deposition in the llama crias studied, estimates for all 3 measurement periods were calculated by using published data from llama carcass analysis, where BW gain was considered to contain $26 \%$ protein and 3\% fat (Condori et al., 2001).

\section{Milk Composition}

Milk samples from each dam for the corresponding measurement periods (wk 3, 10, and 18) were analyzed for fat, protein, lactose, and fat-free DM determined by infrared absorption using an infrared spectral-photometer (Milkoscan FT 6500, Foss Electric, Hillerød, Denmark). The collected amount ranged from 50 to $110 \mathrm{~mL}$. Gross energy (GE) was estimated using the equation after Perrin (1958): GE (MJ/100 g) $=39.8($ fat \% $)+23.9$ (protein \%) + 16.7 (lactose \%). Dry matter concentration of milk was calculated by adding the fat concentration of the milk to the fat-free DM. For one female that could not be handled for milking, the average milk composition of the other animals $(\mathrm{n}=10)$ was used for further computations. A detailed description of the methods 
Table 2. Body water turnover in suckling llama crias $(\mathrm{n}=11)^{1}$

\begin{tabular}{|c|c|c|c|c|c|c|}
\hline Time postpartum (d) & BW (kg) & $\begin{array}{l}\text { Weight } \\
\text { gain }(g / d)\end{array}$ & $\begin{array}{l}\text { Fractional } \\
\text { turnover } \\
\text { (per d) }\end{array}$ & $\begin{array}{l}\text { Body water } \\
(\mathrm{kg})\end{array}$ & $\begin{array}{l}\text { Water } \\
\text { fraction } \\
(\%)\end{array}$ & $\begin{array}{l}\text { Water intake } \\
(\mathrm{kg} / \mathrm{d})\end{array}$ \\
\hline 17 & $18.70 \pm 1.40^{\mathrm{a}}$ & $362 \pm 32^{\mathrm{a}}$ & $0.160 \pm 0.005^{\mathrm{a}}$ & $13.37 \pm 0.93^{\mathrm{a}}$ & $72 \pm 1$ & $2.40 \pm 0.20^{\mathrm{a}}$ \\
\hline 128 & $46.91 \pm 3.94^{\mathrm{c}}$ & $282 \pm 20^{c}$ & $0.055 \pm 0.004^{\mathrm{c}}$ & $32.80 \pm 2.56^{\mathrm{c}}$ & $70 \pm 1$ & $1.79 \pm 0.18^{\mathrm{c}}$ \\
\hline \multicolumn{7}{|c|}{ Two-way ANOVA ( $P$-value $)$} \\
\hline Animal effect & $<0.001$ & $<0.001$ & $<0.05$ & $<0.001$ & $<0.05$ & $<0.001$ \\
\hline
\end{tabular}

${ }^{a-c}$ Means in a column with no common superscript letter differ significantly $(P<0.05)$ based on Student-Newman-Keuls multiple range test for multiple comparisons.

${ }^{1}$ Values are means \pm SEM.

used and the results are given elsewhere (Riek and Gerken, 2006).

\section{Statistical Analyses}

Statistical analyses were performed with the program package SAS version 8.01 (SAS Institute, 19992000). There were no significant differences between the 2 trials and data from both trials were pooled. The influences of the cria's sex and parity were not significant. Accordingly, a 2-way ANOVA was performed using the GLM procedure with animal as random and age as fixed effects. An integrated multiple-range test (Student-Newman-Keuls) was used to detect differences between means with a $5 \%$ significance level. Maintenance requirement for the first measurement period (wk 3) was calculated by the linear regression of growth rate on energy intake, with both variables scaled to metabolic size to 0.83 power to correct for confounding size effects.

The intake of milk constituents was calculated by combining the present milk intake results with the respective milk composition data previously published (Riek and Gerken, 2006).

\section{RESULTS}

Body weight, daily weight gain, and body water turnover for the 3 measurement periods are presented in Table 2. Fractional turnover rate per day and daily water intake decreased significantly with age, whereas body water content remained constant. Daily water intake differed both among crias and age $(P<0.001)$ and was equivalent to $12.9 \pm 0.5,6.7 \pm 0.4$, and $3.9 \pm 0.3 \%$ of cria BW at 17,66 , and $128 \mathrm{~d} \mathrm{PP}$, respectively.

Calculated daily milk intake decreased $(P<0.001)$ with age in all crias when expressed as daily amount, percentage of $\mathrm{BW}$, or per $\mathrm{kg}$ of $\mathrm{BW}^{0.75}$ (Table 3). However, the influence of age was eliminated $(P=0.21)$ when expressed per gram of daily weight gain.
Because llamas only have one cria per parturition, the daily amount of milk ingested by the crias can be also used as an indirect measure of milk output by the dam (Table 4). Milk output varied considerably between animals $(P<0.001)$ and was equivalent to $1.8 \pm 0.1,1.6$ \pm 0.2 , and $1.4 \pm 0.1 \%$ of the dams BW for the $\mathrm{d} 17,66$, and $128 \mathrm{PP}$.

The intake of milk constituents was calculated by combining the present milk intake with the respective milk composition data (Riek and Gerken, 2006; Table 5). When calculated per day or per $100 \mathrm{~g}$ of BW, nutrients as well as energy intakes from the dam's milk decreased significantly with age. As outlined for milk intake, the influence of age was absent when calculations were based on daily weight gain.

Because milk was the only nutrient source in the first measurement period (d $17 \mathrm{PP}$ ), total energy intake and growth data could be used to estimate the maintenance requirement at this age by regression analysis. Predicted maintenance at zero growth was $312 \mathrm{~kJ} / \mathrm{kg}$ of $\mathrm{BW}^{0.83}$ (Figure 1).

\section{DISCUSSION}

\section{Water Turnover}

The fractional water turnover rate decreased with increasing age of the crias (Table 2). The same observation was made for foals (Oftedal et al., 1983) and lambs (Oftedal, 1981). The highest fractional turnover at d 17 PP corresponds to a biological half-life of $4.3 \mathrm{~d}$, which is nearly identical to the value of $4.0 \mathrm{~d}$ obtained for lambs of the same age (Oftedal, 1981). With lower fractional turnover the biological half-life increases and accordingly the biological half-life corresponded to 7.9 and $12.6 \mathrm{~d}$ in the subsequent measurement periods (2 and 3), respectively. In contrast to the present results for growing llamas, Marcilese et al. (1994) showed that a lactating llama takes approximately $3.3 \mathrm{~d}$ to turn over half of the body water, but the lactational stage was 
Table 3. Comparison of milk intakes of suckling llama crias $(\mathrm{n}=11)^{1}$

\begin{tabular}{lllll}
\hline $\begin{array}{l}\text { Time postpartum } \\
(\mathrm{d})\end{array}$ & $\begin{array}{l}\text { Daily milk } \\
\text { intake }(\mathrm{kg})\end{array}$ & $\begin{array}{l}\% \text { of BW } \\
(\%)\end{array}$ & $\begin{array}{l}\text { Per kg of } \\
\mathrm{BW}^{0.75}(\mathrm{~g})\end{array}$ & $\begin{array}{l}\text { Per g of } \\
\text { growth }(\mathrm{g})\end{array}$ \\
\hline 17 & $2.59 \pm 0.21^{\mathrm{a}}$ & $13.94 \pm 0.51^{\mathrm{a}}$ & $288 \pm 11^{\mathrm{a}}$ & $7.2 \pm 0.2$ \\
66 & $2.27 \pm 0.22^{\mathrm{b}}$ & $7.24 \pm 0.46^{\mathrm{b}}$ & $170 \pm 10^{\mathrm{b}}$ & $7.3 \pm 0.3$ \\
128 & $1.95 \pm 0.19^{\mathrm{c}}$ & $4.22 \pm 0.29^{\mathrm{c}}$ & $109 \pm 7^{\mathrm{c}}$ & $6.8 \pm 0.3$ \\
$\begin{array}{l}\text { Two-way ANOVA } \\
\text { Animal effect }\end{array}$ & $<0.001$ & & & \\
Age effect & $<0.001$ & $<0.001$ & $<0.001$ & 0.21 \\
\hline
\end{tabular}

${ }^{\mathrm{a}-\mathrm{c}}$ Means in a column with no common superscript letter differ significantly $(P<0.05)$ based on StudentNewman-Keuls multiple range test for multiple comparisons.

${ }^{1}$ Values are means \pm SEM.

Table 4. Comparison of milk output of llamas $(n=11)$

\begin{tabular}{|c|c|c|c|c|c|c|c|c|}
\hline \multirow{3}{*}{$\begin{array}{l}\text { Time postpartum } \\
\text { (d) }\end{array}$} & \multicolumn{8}{|c|}{ Daily milk output $^{1}$} \\
\hline & \multicolumn{4}{|c|}{$(\mathrm{kg})$} & \multicolumn{4}{|c|}{$\left(\mathrm{g} / \mathrm{kg}\right.$ of $\left.\mathrm{BW}^{0.75}\right)$} \\
\hline & Mean & $\mathrm{SD}$ & Minimum & Maximum & Mean & $\mathrm{SD}$ & Minimum & Maximum \\
\hline 17 & $2.59^{\mathrm{a}}$ & 0.70 & 1.61 & 3.97 & $62.0^{\mathrm{a}}$ & 15.6 & 40.0 & 96.9 \\
\hline 66 & $2.27^{\mathrm{b}}$ & 0.73 & 1.53 & 3.36 & $54.7^{\mathrm{b}}$ & 15.4 & 32.9 & 82.0 \\
\hline 128 & $1.95^{\mathrm{c}}$ & 0.62 & 1.24 & 3.27 & $47.3^{\mathrm{c}}$ & 13.9 & 27.6 & 80.2 \\
\hline \multicolumn{9}{|l|}{ Two-way ANOVA } \\
\hline Animal effect & & & $<0.001$ & & & & $<0.001$ & \\
\hline Age effect & & & $<0.001$ & & & & $<0.001$ & \\
\hline
\end{tabular}

${ }^{\mathrm{a}-\mathrm{c}}$ Means in a column with no common superscript letter differ significantly $(P<0.05)$ based on StudentNewman-Keuls multiple range test for multiple comparisons.

${ }^{1}$ Output equivalent to intake.

Table 5. Nutrient intakes of suckling llama crias from dam's milk $(n=11)^{1}$

\begin{tabular}{|c|c|c|c|c|c|}
\hline \multirow[b]{3}{*}{ Nutrient } & \multirow{2}{*}{\multicolumn{3}{|c|}{ Time postpartum (d) }} & \multicolumn{2}{|c|}{$\begin{array}{c}\text { Two-way ANOVA } \\
(P \text {-value })\end{array}$} \\
\hline & & & & \multirow{2}{*}{$\begin{array}{l}\text { Animal } \\
\text { effect }\end{array}$} & \multirow{2}{*}{$\begin{array}{l}\text { Age } \\
\text { effect }\end{array}$} \\
\hline & 17 & 66 & 128 & & \\
\hline \multicolumn{6}{|l|}{ Per day } \\
\hline DM (g) & $403 \pm 34^{\mathrm{a}}$ & $350 \pm 34^{\mathrm{b}}$ & $303 \pm 27^{\mathrm{c}}$ & $<0.001$ & $<0.001$ \\
\hline Fat (g) & $112 \pm 8^{\mathrm{a}}$ & $102 \pm 11^{\mathrm{ab}}$ & $92 \pm 9^{b}$ & $<0.001$ & $<0.05$ \\
\hline Protein (g) & $107 \pm 8^{\mathrm{a}}$ & $93 \pm 10^{\mathrm{ab}}$ & $82 \pm 7^{b}$ & $<0.001$ & $<0.01$ \\
\hline Lactose (g) & $155 \pm 13^{\mathrm{a}}$ & $138 \pm 13^{b}$ & $114 \pm 10^{\mathrm{c}}$ & $<0.001$ & $<0.001$ \\
\hline Gross energy (kJ) & $9,591 \pm 727^{\mathrm{a}}$ & $8,587 \pm 849^{b}$ & $7,518 \pm 691^{\mathrm{c}}$ & $<0.001$ & $<0.01$ \\
\hline \multicolumn{6}{|l|}{ Per $100 \mathrm{~g}$ of $\mathrm{BW}$} \\
\hline $\mathrm{DM}(\mathrm{g})$ & $2.16 \pm 0.08^{\mathrm{a}}$ & $1.15 \pm 0.08^{\mathrm{b}}$ & $0.66 \pm 0.04^{\mathrm{c}}$ & $<0.01$ & $<0.001$ \\
\hline Fat $(\mathrm{g})$ & $0.60 \pm 0.01^{\mathrm{a}}$ & $0.34 \pm 0.03^{\mathrm{b}}$ & $0.20 \pm 0.01^{\mathrm{c}}$ & $<0.05$ & $<0.001$ \\
\hline Protein (g) & $0.58 \pm 0.02^{\mathrm{a}}$ & $0.30 \pm 0.02^{\mathrm{b}}$ & $0.18 \pm 0.01^{\mathrm{c}}$ & 0.07 & $<0.001$ \\
\hline Lactose (g) & $0.83 \pm 0.03^{\mathrm{a}}$ & $0.45 \pm 0.03^{b}$ & $0.25 \pm 0.02^{\mathrm{c}}$ & $<0.01$ & $<0.001$ \\
\hline Gross energy (kJ) & $52 \pm 1^{\mathrm{a}}$ & $28 \pm 2^{\mathrm{b}}$ & $16 \pm 1^{\mathrm{c}}$ & $<0.05$ & $<0.001$ \\
\hline \multicolumn{6}{|l|}{ Per g of gain } \\
\hline $\mathrm{DM}(\mathrm{g})$ & $1.12 \pm 0.01$ & $1.13 \pm 0.06$ & $1.06 \pm 0.04$ & 0.20 & 0.41 \\
\hline Fat (g) & $0.31 \pm 0.01$ & $0.33 \pm 0.02$ & $0.32 \pm 0.02$ & 0.28 & 0.77 \\
\hline Protein (g) & $0.30 \pm 0.01$ & $0.30 \pm 0.02$ & $0.29 \pm 0.01$ & 0.71 & 0.79 \\
\hline Lactose $(\mathrm{g})$ & $0.43 \pm 0.01^{\mathrm{a}}$ & $0.45 \pm 0.02^{\mathrm{ab}}$ & $0.40 \pm 0.01^{\mathrm{a}}$ & 0.50 & 0.13 \\
\hline Gross energy (kJ) & $27 \pm 1$ & $28 \pm 2$ & $26 \pm 1$ & 0.42 & 0.67 \\
\hline
\end{tabular}

${ }^{a-c}$ Means in a row with no common superscript letter differ significantly $(P<0.05)$ based on StudentNewman-Keuls multiple range test for multiple comparisons.

${ }^{1}$ Values are means \pm SEM. 


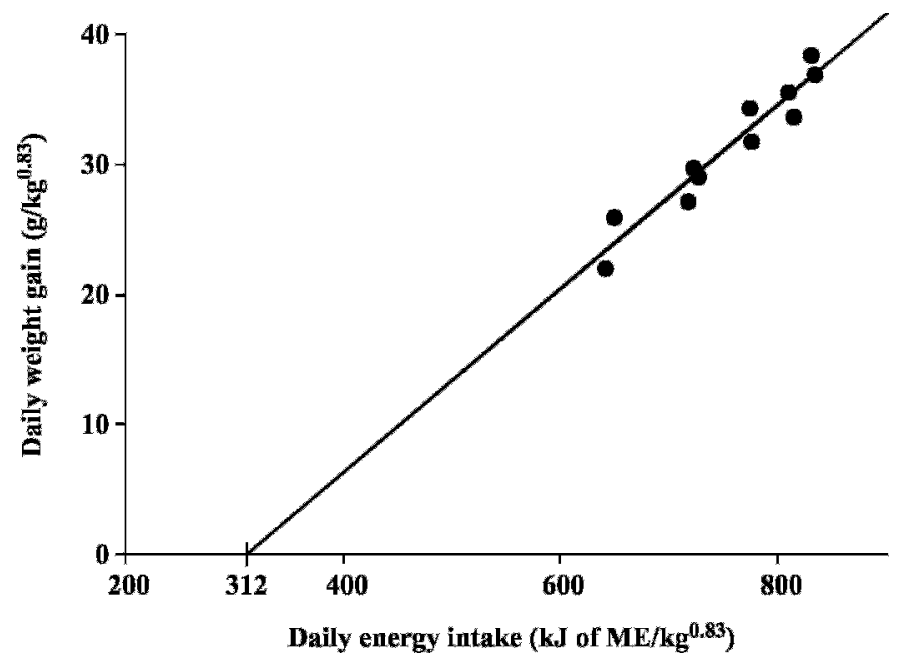

Figure 1. The relationship between daily weight gain and ME intake in suckling llama crias $(\mathrm{n}=11)$ at peak lactation ( $17 \mathrm{~d}$ postpartum). Predicted maintenance (at zero growth) is $312 \mathrm{~kJ}$ of $\mathrm{ME} / \mathrm{kg}^{0.83}$ per d $\left(\mathrm{y}=-22.12+0.071 \mathrm{x} ; \mathrm{R}^{2}=0.92 ; P<0.01\right)$.

not given. This difference may be explained by the higher water demand due to milk production. At peak lactation, dams consume approximately $9.8 \mathrm{~L}$ of water per day, whereas in late lactation they only consume about 5.5 L (A. Riek, unpublished data).

Body water remained constant across ages with a nonsignificant decreasing trend (Table 2). The estimates of body water in crias in the present study were very close to values obtained by isotope labeling for kids (Makinde, 1993) and lambs (Dove, 1988) of similar ages. Marcilese et al. (1994) report a value of $71 \%$ body water in a 14-d-old cria by using isotope labeling, which is very close to the present results. Dilution studies on adult llamas of 3 to $6 \mathrm{yr}$ revealed lower values ranging from 60 to $70 \%$ (Rübsamen and Engelhardt, 1975). However, it is known that body water content decreases with age primarily due to fat accumulation (Oftedal and Iverson, 1989).

\section{Milk Output and Intake}

To compare milk output and milk intake among several species, the peak lactation was chosen as most representative phase of the lactation (Oftedal, 1984). In Table 6, the present data and results from the literature were used to express milk output and intake on different bases. For a valid comparison, only data from meattype domesticated ruminants were included.

To the authors' knowledge there are no published data on either llama milk production yields or milk intakes. Peak lactation in the llama seems to appear around wk $3 \mathrm{PP}$ and lasts only for a short time of about

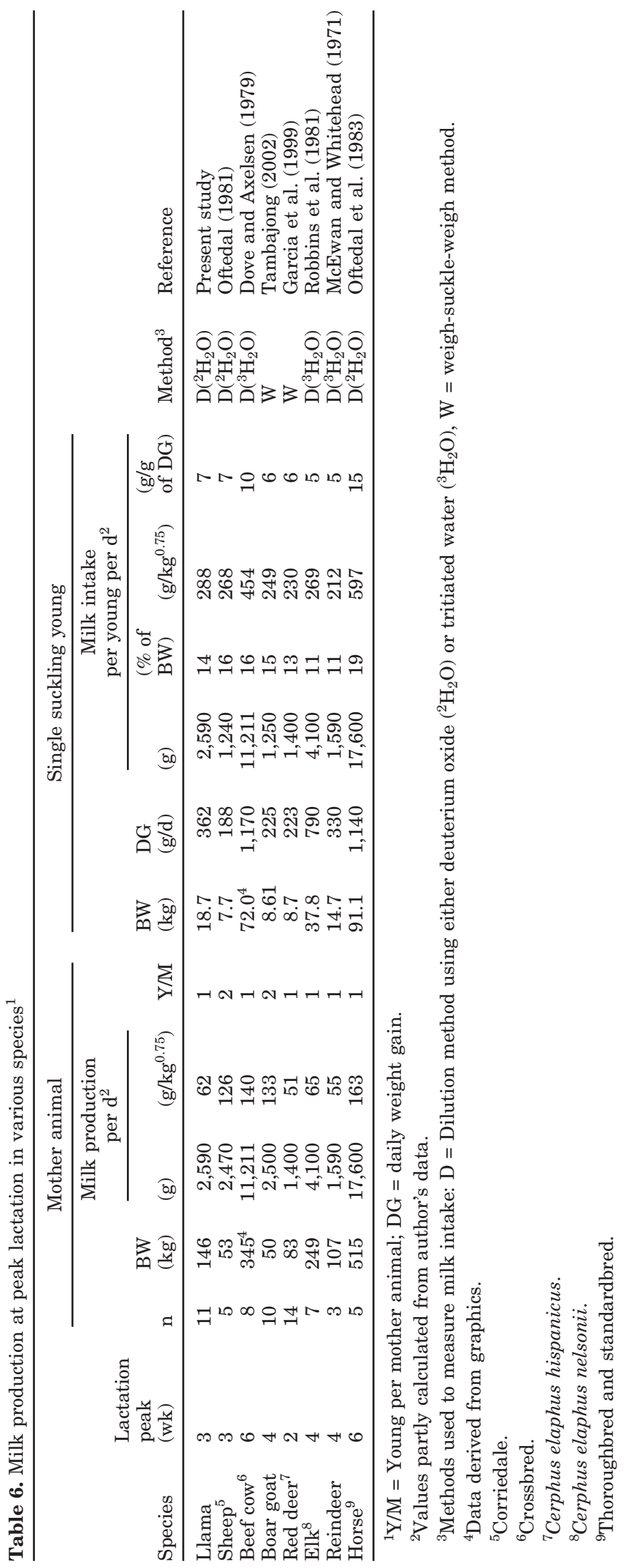


1 to 2 wk (Riek and Gerken, 2006). The estimated daily milk output at peak lactation for the llama is most comparable to sheep and meat goats. Both produce approximately $2.5 \mathrm{~L} / \mathrm{d}$ of milk at peak lactation, which is similar to the present values found for llamas. However, the milk yield in small ruminants may vary substantially, depending on whether singles or twins are nursed. Compared on the basis of daily milk production per $\mathrm{kg}$ of $\mathrm{BW}^{0.75}$, the results for llamas are closer to wild rather than domestic ruminants. This observation can be probably attributed to the fact that New World camelids were never selected for milk production. Contrarily, domestic ruminants selected for milk yield over a long time such as dairy cows and milk goats produce depending on the breed up to 400 (Eastridge, 2006) and $200 \mathrm{~g} / \mathrm{d}$ per $\mathrm{kg} \mathrm{BW}{ }^{0.75}$ (Min et al., 2005), respectively. The high variations between animals in milk yields found in the present study (Table 4) indicate the existence of a considerable phenotypic variation and suggest that a genetic selection for higher milk yields in llamas could be possible.

Looking at the milk intakes of the young, the llama cria consumes approximately double the amount compared with twins of lambs or kids, resulting in higher daily gains. However, this comparison is biased because single lambs or kids have higher milk intakes and growth rates compared with twins. Comparing milk intake on a percentage of BW basis, the value for llama crias is lower (14\%) than that of domestic ruminants but higher than that of wild ruminants. Crias consumed more milk per $\mathrm{kg}$ of $\mathrm{BW}^{0.75}$ than wild and small domestic ruminants, whereas foals and calves seem to consume more milk per kilogram of $\mathrm{BW}^{0.75}$. The same differences exist among species when milk intake is expressed per gram of daily gain.

From d 17 to 66 PP, both milk intakes and daily gains decreased by $12 \%$, whereas from d 66 to $128 \mathrm{PP}$, milk intake decreased by $14 \%$, and daily gains decreased only by $10 \%$. This divergence suggests that, from around wk $10 \mathrm{PP}$, milk was no longer the main nutrient source. Although water intake was restricted to milk in the measurement periods, additional water consumed from hay could have resulted in an overestimation of the amount of milk ingested. Assuming a daily DMI of $1 \%$ of BW (Van Saun, 2006) through hay and a water content of the hay of $140 \mathrm{~g}$ of water $/ \mathrm{kg}$ of fresh matter, crias would have consumed $2 \%$ (at $66 \mathrm{~d} \mathrm{PP}$ ) and $5 \%$ (at $128 \mathrm{~d} \mathrm{PP}$ ) of the total water from food, which is close to the value reported by Marcilese et al. (1994) for adult llamas. Milk intakes for the measurement periods at 66 and $128 \mathrm{~d} \mathrm{PP}$ would then have been overestimated by 7 and $10 \%$, respectively.

\section{Energy and Nutrient Intake}

Total energy intakes could only be determined for the first measurement period, because crias started to ingest hay from wk $4 \mathrm{PP}$ onwards and separate hay feeding of dams and young was not possible. With milk as the only nutrient source at $17 \mathrm{~d} \mathrm{PP}$, the daily total energy consumed averaged 9.59 MJ of GE (Table 4), which corresponds to 8.63 MJ of ME under the assumption that $\mathrm{ME}$ in milk is equivalent to 90 to $95 \%$ of GE. Oftedal (1981) showed that the energy intakes of suckling young are not proportional to $\mathrm{BW}^{0.75}$ as in adult mammals, but rather to $\mathrm{BW}^{0.83}$. Accordingly, llama crias consumed $754 \mathrm{~kJ}$ of $\mathrm{ME} / \mathrm{kg}$ of $\mathrm{BW}^{0.83}$ or 838 $\mathrm{kJ}$ of $\mathrm{GE} / \mathrm{kg}$ of $\mathrm{BW}^{0.83}$ at peak lactation, which is close to the value of $942 \mathrm{~kJ}$ of $\mathrm{GE} / \mathrm{kg}$ of $\mathrm{BW}^{0.83}$ derived by Oftedal (1981) from milk intake data of several species at peak lactation, including domestic and wild ruminants.

Oftedal (1981) showed that weight gains are also proportional to $\mathrm{BW}^{0.83}$ if the only nutrient source is milk. Based on studies in several species, Oftedal (1981) found a growth rate of $33 \mathrm{~g} / \mathrm{kg}$ of $\mathrm{BW}^{0.83}$, which is in agreement with the value of $31 \mathrm{~g} / \mathrm{kg}$ of $\mathrm{BW}^{0.83}$ obtained in the present study for llamas.

Only 2 studies determined the maintenance requirements for llamas in adult animals (Schneider et al., 1974; Carmean et al., 1992). Based on these results, Van Saun (2006) suggests an average value for maintenance of $305 \mathrm{~kJ} / \mathrm{d}$ of $\mathrm{ME} / \mathrm{kg}$ of $\mathrm{BW}^{0.75}$ for llamas. However, these values are not applicable for crias, whose only nutrient source is milk, because the respective variables need to be scaled to metabolic size to 0.83 power. As shown in Figure 1, predicted maintenance at zero growth for suckling llamas at peak lactation is $312 \mathrm{~kJ} / \mathrm{d}$ per $\mathrm{kg}$ of $\mathrm{BW}^{0.83}$ corresponding to $3.55 \mathrm{MJ}$ of $\mathrm{ME}$. The remaining $\mathrm{ME}$ from the energy consumed (5.08 $\mathrm{MJ} / \mathrm{d}$ of $\mathrm{ME}$ ) is then assumed to be used for growth and corresponds to $14 \mathrm{~kJ}$ of $\mathrm{ME} / \mathrm{g}$ of weight gain. This estimate is nearly the same as that reported by Johnson (1994) for suckling llamas, but no methodology was described.

Nutrient intake at peak lactation is apparently not proportional to $\mathrm{BW}^{0.83}$, except for protein (Oftedal, 1981). Van Saun (2006) suggested a protein requirement of $3.5 \mathrm{~g} / \mathrm{kg}$ of $\mathrm{BW}^{0.75}$ for maintenance plus 0.284 g/g of weight gain. For the present study, total protein requirements would then amount to 134, 135, and 143 $\mathrm{g} / \mathrm{d}$ at d 17, 66, and $128 \mathrm{PP}$, respectively. Assuming that at peak lactation, protein intake is not proportional to $\mathrm{BW}^{0.75}$ but to $\mathrm{BW}^{0.83}, 134 \mathrm{~g}$ at wk 3 would seem to overestimate the total protein requirement. Oftedal (1981) showed that total protein requirement at peak lactation averages $10.6 \mathrm{~g}$ per $\mathrm{BW}^{0.83}$ and that actual 
intakes varied within $\pm 15 \%$ of predicted intakes for 10 species. Applying this model to the present BW data, estimated total protein requirement of crias is $120 \mathrm{~g} / \mathrm{d}$ at peak lactation, which is only $13 \mathrm{~g}$ more than the actual measured $107 \mathrm{~g} / \mathrm{d}$ (Table 4) or $89 \%$ of the predicted $120 \mathrm{~g}$. Apparently, the llama fits within the model developed by Oftedal (1981).

\section{CONCLUSIONS}

The study showed that using $\mathrm{D}_{2} \mathrm{O}$ dilution to measure milk intake in suckling llamas gives reasonable estimates of the milk intake. The comparisons across different ruminant species indicate that milk production in llamas lies between that of wild and domestic ruminants used for meat production. Accordingly, it is suggested that, during domestication of the llama, there was neither strong direct selection pressure on milk yield nor indirect selection on increased milk yield via selection for growth performance as in beef cattle. Thus, the results support the model of Lauvergne (1994) who characterized South American llamas as "primary populations" after the domestication. The scarce food availability of natural pastures in the High Andes together with the milking difficulties met in llamas might have hindered artificial selection for higher milk yields under traditional South American conditions.

By combining the present milk intake estimates with milk composition data, energy and nutrient intakes from milk can be calculated, which in turn may help in establishing reference values for energy and nutrient requirements for crias. These estimates can be used to compose milk replacers for nursing llamas whose dams are agalactic or have died. In addition, the present results might be helpful in the formulation of nutrient requirements of lactating dams. Because this was the first study examining llama milk intake, further systematic studies are needed.

\section{ACKNOWLEDGMENTS}

The authors wish to acknowledge the financial support from the European Union (DECAMA project, contract No. ICA4-CT-2002-10014). M. Gauly is specially thanked for the veterinary advice. We wish to thank J. Langel for organizing the deuterium oxide analyses and the Messing and Kraft families for their support by lending animals. We would also like to thank M. Schlote and F. Güthoff for organizing the vaccum sublimation. The technical assistance of A. Oppermann and K. Salzmann of the Experimental Station Relliehausen, and J. Dörl and the technical staff of the Institute of Animal Breeding and Genetics of the University of Goettingen is highly appreciated.

\section{REFERENCES}

Auchtung, T. L., D. J. Baer, R. A. Erdman, S. M. Barao, and G. E. Dahl. 2002. Relation of growth hormone response to growth hormone-releasing hormone to estimation of milk production via deuterium oxide dilution in beef cattle. J. Anim. Sci. 80:12701274.

Caire, G., A. M. Calderon de la Barca, A. V. Bolanos, M. E. Valencia, A. W. Coward, G. Salazar, and E. Casanueva. 2002. Measurement of deuterium oxide by infrared spectroscopy and isotope ratio mass spectrometry for quantifying daily milk intake in breastfed infants and maternal body fat. Food Nutr. Bull. 23(Suppl. 3):38-41.

Cameron, E. Z. 1998. Is suckling behaviour a useful predictor of milk intake? A review. Anim. Behav. 56:521-532.

Carmean, B. R., K. A. Johnson, D. E. Johnson, and L. W. Johnson. 1992. Maintenance energy requirement of llamas. Am. J. Vet. Res. 53:1696-1698.

Condori, G., C. Renieri, C. Ayala, T. Rodriguez, and Z. Martinez. 2001. Estudio y caracterizacion de la aptitud de produccion de carne en llamas (Lama glama). Pages 211-236 in Progress in South American camelids research; Proc. 3rd Eur. Symp., SUPREME European seminar, Goettingen, Germany. M. Gerken and C. Renieri, ed. Wageningen Academic Press, Wageningen, the Netherlands.

Dove, H. 1988. Estimation of the intake of milk by lambs, from the turnover of deuterium- or tritium-labelled water. Br. J. Nutr. 60:375-387.

Dove, H., and A. Axelsen. 1979. Estimation of milk consumption in beef calves using a tritiated water dilution technique. Aust. J. Exp. Agric. Anim. Husb. 19:666-672.

Eastridge, M. L. 2006. Major advances in applied dairy cattle nutrition. J. Dairy Sci. 89:1311-1323.

Fernandez, F. M., and G. Oliver. 1988. Proteins present in llama milk. I. Quantitative aspects and general characteristics. Milchwissenschaft 43:299-302.

Fowler, M. E. 1989. Medicine and surgery of South American camelids: Llama, Alpaca, Vicuna, Guanaco. Iowa State University Press, Ames.

Garcia, A., T. Landete-Castillejos, A. Molina, B. Albinana, C. Fernandez, J. Garde, and L. Gallego. 1999. Lactation curves in captive Iberian red deer (Cervus elaphus hispanicus). J. Anim. Sci. 77:3150-3155.

Gauthier, D., and C. Barrette. 1985. Suckling and weaning in captive white-tailed and fallow deer. Behaviour 94:128-149.

Glencross, B. D., B. P. Mullan, R. C. Tuckey, and P. E. Hartmann. 1997. A simplification of the deuterium oxide dilution technique using FT-IR analysis of plasma, for estimating piglet milk intake. Aust. J. Agric. Res. 48:1099-1104.

Holleman, D. F., R. G. White, and J. R. Luick. 1982. Application of the isotopic water method for measuring total body water, body composition and body water turnover. Pages 9-32 in Use of tritiated water in studies of production and adaptation in ruminants. International Atomic Energy Agency, Vienna, Austria.

Johnson, L. W. 1994. Llama nutrition. Vet. Clin. North Am. Food Anim. Pract. 10:187-200.

Lauvergne, J. J. 1994. Characterization of domesticated genetic resources in American camelids: A new approach. Pages 59-63 in Eur. Symp. South American Camelids Proc., Bonn, Germany. M. Gerken and C. Renieri, ed. Università degli studi di Camerino, Camerino, Italy.

Leyva, V., and J. Markas. 1991. Involucion de la glandula mamaria en alpacas y efecto sobre el peso corporal y produccion de fibra. Turrialba 41:59-63.

Macfarlane, W. V., B. Howard, and B. D. Sierbert. 1969. Tritiated water in the measurement of milk intake and tissue growth of ruminants in the field. Nature 221:578-579.

Makinde, M. O. 1993. Isotopic water dilution technique in body fluid measurement in some domestic animal species. J. Vet. Med. Ser. A 40:582-586.

Marcilese, N. A., M. D. Ghezzi, M. A. Aba, R. A. Alzola, H. Solana, and R. M. Valsecchi. 1994. Physiological studies in the South 
American camelid llama (Lama guanicoe f. d. glama). I. Body water spaces and water turnover. Acta Physiol. Pharmacol. Ther. Latinoam. 44:36-42.

McEwan, E. H., and P. E. Whitehead. 1971. Measurement of the milk intake of reindeer and caribou calves using tritiated water. Can. J. Zool. 49:443-447.

Min, B. R., S. P. Hart, T. Sahlu, and L. D. Satter. 2005. The effect of diets on milk production and composition and on lactation curves in pastured dairy goats. J. Dairy Sci. 88:2604-2615.

Morin, D. E., L. L. Rowan, W. L. Hurley, and W. E. Braselton. 1995. Composition of milk from llamas in the United States. J. Dairy Sci. 78:1713-1720.

Oftedal, O. T. 1981. Milk, protein and energy intakes of suckling mammalian young: A comparative study. Ph.D. Diss., Cornell Univ., Ithaca, NY.

Oftedal, O. T. 1984. Milk composition, milk yield and energy output at peak lactation: A comparative review. Symp. Zool. Soc. Lond. $51: 33-85$.

Oftedal, O. T., H. F. Hintz, and H. F. Schryver. 1983. Lactation in the horse: Milk composition and intake by foals. J. Nutr. 113:2196-2206.

Oftedal, O. T., and S. J. Iverson. 1989. Hydrogen isotope methodology for measurement of milk intake and energetics of growth in suckling young. Pages 67-96 in Approaches to marine mammal energetics. Society for Marine Mammalogy, special publication no. 1. A. C. Huntley, D. P. Costa, G. A. J. Worthy, and M. A. Castellini, ed. Allen Press, Lawrence, KS.

Perrin, D. R. 1958. The calorific value of milk of different species. J. Dairy Res. 25:215-220.

Pouillon, C. 2001. Untersuchungen zum Mutter-Kind-Verhalten von Lamas (Lama glama) unter besonderer Berücksichtigung des Saug- und Säugeverhaltens. PhD Diss. Giessen Univ., Germany.
Riek, A., and M. Gerken. 2006. Changes in llama (Lama glama) milk composition during lactation. J. Dairy Sci. 89:3484-3493.

Robbins, C. T., R. S. Podbielancik-Norman, D. L. Wilson, and E. D. Mould. 1981. Growth and nutrient consumption of elk calves compared to other ungulate species. J. Wildl. Manage. 45:172186.

Rübsamen, K., and W. v. Engelhardt. 1975. Water metabolism in the llama. Comp. Biochem. Physiol. A 52:595-598.

SAS Institute. 1999-2000. SAS User's Guide: Statistics. Release 8.01. SAS Inst. Inc., Cary, NC.

Schneider, W., R. Hauffe, and W. v. Engelhardt. 1974. Energie- und Stickstoffumsatz beim Lama. Pages 121-130 in Energy Metabolism of Farm Animals. Eur. Assoc. Anim. Prod., Hohenheim Dok, Stuttgart, Germany.

Schoeller, D. A., E. Ravussin, Y. Schutz, K. J. Acheson, P. Baertschi, and E. Jequier. 1986. Energy expenditure by doubly-labelled water: Validation in humans and proposed calculation. Am. J. Physiol. 250:R823-R830.

Tambajong, D. D. S. J. 2002. Geburt, Saugverhalten und Milchparameter bei Burenziegen. PhD Diss. Goettingen Univ., Goettingen, Germany.

Van Es, A. J. H. 1969. Report to the subcommittee on constants and factors: Constants and factors regarding metabolic water. Pages 513-514 in Energy metabolism and farm animals. K. L. Blaxter, J. Kielanowski, and G. Thorbek, ed. Oriel Press, Newcastle upon Tyne, UK.

Van Saun, R. J. 2006. Nutrient requirements of South American camelids: A factorial approach. Small Rumin. Res. 61:165-186.

Wong, W. W., and D. A. Schoeller. 1990. Mass Spectrometric Analysis. Pages 20-47 in The doubly labelled water method for measuring energy expenditure: Technical recommendations for the use on humans. A. M. Prentice, ed. International Atomic Energy Agency, Vienna, Austria. 